\title{
System Innovation in the Construction of the Silk Road Economic Region in China
}

\author{
Zhang HongLi \\ Management School \\ Xian University of Science and Technology \\ Xian, China, \\ honglizhang@sina.com,475674939@qq.com
}

\begin{abstract}
Abstrac-System innovation is the major impetus for the development of modern economy and society. At present, the System issues are still the biggest obstacle in the way of further marketizing and internationalizing Chinese economy, they are the priority problem must be faced and solved when developing Silk Road Economic Region. The system of administrative management, financial and taxation system as well as investment and financing in our nation cannot satisfy the demands. This paper proposed a basic thinking on the System innovation, which believes that System innovation in the aspects of administrative management, finance and taxation, investment and financing should be actively pushed forward to bring in steady impetus for the development of Silk Road Economic Region.
\end{abstract}

Keywords-Silk Road; economic region; System; innovation ;impetus

\section{INTRODUCTION}

The Silk Road is the main trade gateway among the ancient China and Central Asian as well as European countries. In September 2013, Chinese President Xi Jinping proposed a new mode of regional economic cooperation when visiting Kazakhstan - "New Silk Road Economic Region". This strategy intends to bind Europe and Asia, which are now the most active economic regions, more closely, and to promote the prosperity of trade and economies as well as the exchanges and integration of eastern and western civilization. Once being proposed, this strategy was actively responded and supported within the international community. Domestic western provinces also demonstrated positive actions to strive for benefits from this scarce historic opportunity and to fully accelerate the development of economy and society.

\section{SYSTEM INNOVATION IS THE MAJOR IMPETUS FOR THE ECONOMIC AND SOCIAL DEVELOPMENT}

Joseph Alois Schumpeter is the founder of modern theory of innovation. He categorized innovation into product innovation, technological innovation, market innovation, resource distribution innovation and organizational innovation, among which organizational innovation, market innovation and resource distribution innovation belong to System innovation. Based on the innovation theory proposed by Schumpeter, innovation, especially System innovation, is the foundation of continuous perfection and development of capitalism, the major impetus for the economic and social development and the source driving the sustainable development.

\section{A. Prosperity of Modern Countries Mainly Relies on System Innovation}

From the aspect of economic development momentum, the ancient civilization mainly relied on abundant resources, the powerfulness of former modern countries mainly resulted from scientific and technological progress and the prosperity of modern countries mainly benefit from system innovation. Since the Second World War, tendencies of industrialization, urbanization, informatization, internationalization and marketization in the world have sped up prominently as factors have been able to flow freely within the globe. Under this circumstance, any country or region can attract factors including sufficient talents, capital and technology with system superiority to support its rapid economic development rather than relying on resource superiority. Therefore, the major impetus for pushing forward the prosperity in modern countries is not traditional resource, technological or industrial conditions any more, but continuous innovation of System. The leapfrog development in Four Asian Tigers (Singapore, Taiwan, Hong Kong and South Korea) and the consistent prosperity in BRICS countries are both built on system innovation including reform, opening-up, marketization and democratization. Whatever the replacement of economic centers or the late-developing regions turning into economic growth point, they both depend on location, resource and demographic advantages as well as innovative advantages in system, mechanism and technology $[1][2]$.

\section{B. "China Miracle" Confirms the Significant Role of System Innovation}

Neoinstitutional economics believes that effective organization is the key of economic growth, and the determinant of economic growth performance is system rather then technology. During the 35 years of reform and opening-up, China has implemented a series of productive system innovation at different phrases and in different fields, and achieved remarkable success in economic development(TABLE I.).

The introduction of the household contract responsibility system with remuneration linked to output has greatly enhanced agricultural labor productivity, solved the food and clothing problems for a population of 
hundreds of million and provided a large number of surplus labor for the industrialization. Measures such as state-owned enterprise reform and encouraging the development of private economy have established the microcosmic body of socialist market economy, greatly activated social productivity and promoted social and economic development.

TABLE I. 2005-2013 CHINA'S ECONOMIC GROWTH PERFORMANCE

\begin{tabular}{|c|c|c|c|}
\hline Years & $\begin{array}{c}\text { GDP growth } \\
\text { rate (\%) }\end{array}$ & $\begin{array}{c}\text { GDP per } \\
\text { capita } \\
\text { (yuan) }\end{array}$ & $\begin{array}{c}\text { Per capita disposable } \\
\text { income of urban residents } \\
\text { (yuan) }\end{array}$ \\
\hline 2005 & 11.3 & 14185 & 10493 \\
\hline 2006 & 12.7 & 16500 & 11759.5 \\
\hline 2007 & 14.2 & 20169 & 13785.8 \\
\hline 2008 & 9.6 & 23708 & 15780.8 \\
\hline 2009 & 9.1 & 25608 & 17174.7 \\
\hline 2010 & 10.4 & 30015 & 19109.4 \\
\hline 2011 & 9.2 & 35198 & 21809.8 \\
\hline 2012 & 7.8 & 38449 & 24564.7 \\
\hline 2013 & 7.7 & 41909 & 26955 \\
\hline
\end{tabular}

During the process of closed economy transforming into open economy and of planned economy transforming into market economy, China referred to foreign advanced system and management experience and has implemented a series of System innovation with Chinese characteristics. Great change in Shenzhen Special Economic Zone, prominence of private economy in Jiangsu and Zhejiang and success of Guangdong Four Tigers (Dongguan, Shunde, Fanyu and Zhongshan) can only be explained by System innovation.

At the meeting celebrating the 30th anniversary of China's reform and opening-up, Comrade $\mathrm{Hu}$ Jintao pointed out: "we must actively probe into the System which can greatly release and develop productive forces and fully mobilize the enthusiasm for development within the whole society, maximally inspire the vitality of labor, knowledge, technology, management and capital, and propel the sources creating social wealth to flow to the extreme." This statement has thoroughly summarized the experience of reform and opening-up while highlighting the critical role System innovation has played.

\section{PRESENT Systems Do Not FIT THE DEVELOPMENT OF SILK ROAD ECONOMIC REGION}

Although reform and opening-up has been implemented for more than 30 years, the System issues are still the biggest obstacle in the way of further marketizing and internationalizing Chinese economy[3] Similarly, System obstacle is the priority problem must be faced and solved when developing Silk Road Economic Region.

\section{A. System of Administrative Management is Disadvantageous to Releasing Market Dynamics}

Administrative management system refers to the national administrative establishment, administrative functions and the formed rules and regulations for this purpose. The main problems existing in the national administrative management system are irrational administrative structure, improper distribution of administrative functions, multiple channel management and the resulting problems including onerous administrative approval process, the overlong approval period and uncontrolled power rent-seeking. Hence, the government credit may be weakened and the government function of public service may be whittled. All these issues are nor favorable to the establishment and running of market system nor the enhancement of resource distribution efficiency.

The development of Silk Road Economic Region will necessarily involve the operation of infrastructure and large-scale project, whose approval and management are connected to departments such as land and resources, urban planning, municipal administration and cultural relics and normally require cross-regional and sectional cooperation. The existing problems in current administrative management system may cause greatly prolonged construction cycle and increased construction cost. As a transnational and cross-regional strategy aiming economic development, the construction of Silk Road Economic Region should beak all limits of administrative division, focus on industrial development and key field construction, break administrative limits caused by local government' benefits at different levels from the aspects of administrative institutions, adjustment of organization relationship, formation of related rules and regulations and simplification of corresponding legal process, and fully inspire the vitality of main market players.

\section{B. Financial and Taxation System is Disadvantageous to the Reduction of Trade Cost}

The taxation system reform in 1994 established the basic pattern of the central and local financial resources distribution, and taxation system became a tool of macro control. Through different taxation combination, the central and local governments can guide investment, promote industrial development and adjust economic structure. The system of tax returns and transfer payment is advantageous to the special subsidies for economically undeveloped areas funded by the central government.

Developing Silk Road Economic Region requires attraction of enterprises and investment with fiscal and taxation means to promote industrial development. Therefore, rational financial and taxation system is undoubtedly a powerful tool. Whereas, the nontransparency and non-standardization of current fiscal and taxation system are most prominent in issues such as varied items of administrative charge, various categories of taxes and repetitive taxing ${ }^{\left[{ }^{4]}\right.}$ Being disadvantageous to enterprise investment, the current fiscal and taxation system may cause increased logistics cost and trade cost and to some extent constrain the economic development. The construction of Silk Road Economic Region requires unified and efficient customs procedure among related countries and regions, mutually beneficial and reasonable tariff and low-cost logistics service, which cannot be ensured under the current fiscal and taxation system. 


\section{Investment and Financing System is Disadvantageous to the Enhancement of Investment Efficiency}

The main functions of investment system and financing system are regulating investment and financing behaviors and enabling them to satisfy the demands of social and economic development and requirements of national industry policies. The numerous construction projects involved in the development of Silk Road Economic Region require flexible and highly effective financing channels and financial service as well as scientific and rapid investment decision-making system and approval system.[5] At present, due to the comparatively obsolete benefit concept of public authorities, their service awareness and legal consciousness are weak with occasional insufficient sincerity; besides, the present investment system lacks required flexibility and convenience, powerful support cannot be provided for Silk Road Economic Region especially in the aspect of approving cross-regional and cross-sectional large-scale investment projects. On March 21 2012, titled with "Previous Investment Attraction Turning Into Enclosed Faith Breaking", Shaanxi Business Network reported that during the municipal construction, Baqiao District Government of Xi' an City broke its faith and forced the settled high-tech enterprises through previous investment attraction to remove from the industrial park. This event demonstrates that the working investment system in our nation and the investment attraction policies of local governments are excessively utilitarian and lack required spirit of contract. If there is no obvious improvement on the situation, the leapfrog development of Silk Road Economic Region cannot be realized.

The current financing system cannot either satisfy the development demands of Silk Road Economic Region. Since 2012, the Ministry of Finance, the Central Bank and China Banking Regulatory Commission have issued documents for many times requiring financial institutions at different levels to curb credits extended to local governments. As sufficient funds cannot be gained through proper channels, local governments can only acquire needed finance though varied converted financing means, which will inevitably cause shocks to the required funds for economic development. The construction of Silk Road Economic Region also requires a large amount of funds through financing platform, so investment and financing system reform is essential.

\section{PRomoting The DEVElopment OF SiLK RoAD}

\section{ECONOMIC REGION THROUGH SYSTEM INNOVATION}

The proposal of Silk Road Economic Region strategy brings the adjacent countries and domestic related provinces a hard-won opportunity for development, which should be properly seized to actively push forward System innovation, stimulate the market's vitality, strengthen provincial and international cooperation and promote the development of open economy.

Wherever Times is specified, Times Roman or Times New Roman may be used. If neither is available on your word processor, please use the font closest in appearance to Times. Avoid using bit-mapped fonts if possible. TrueType 1 or Open Type fonts are preferred. Please embed symbol fonts, as well, for math, etc.

\section{A. Innovation of Administrative Management System}

As a regional economic development strategy with international significance, 14 provinces and cities within China have been involved in Silk Road Economic Region, which cover 5 provinces in the northwest, four provinces and cities in the southwest and five provinces in the east. Therefore, breakage of administrative divisions is required for the development of the project. Interest fences and administrative boundaries among governments at different levels should be breached from the aspects of administrative management system reform focusing on industries of priority development and key construction fields, establishment of administrative institutions, adjustment of functional relationship as well as simplification of corresponding legal process. Thus the market vitality can be ignited.

At the national level, a comprehensive management agency in charge of multiple administrative regions, such as a management committee of Silk Road Economic Region, can be takin into consideration. Under the direct leadership and coordination of the State Council, a strategy favorable to sustainable development and covering economic cooperation, social coordination and project development will be formed after overall planing and resources integration. Simultaneously, the market enforcement standards should be unified to ensure the smooth cooperation among provincial and district governments in finance, energy, urban construction, transportation and travel[ 6 ]; mutual connection and coordinated development should be actively promoted among railway, highway, aviation and telecommunication. Round-table conferences participated by mayors of Silk Road related cities should be convened to advance regional cooperation.

At the international level, a economic coordination and cooperation mechanism among Silk Road related countries can be taken into consideration. Related laws and policies in member states, such as customs policy, trade system and energy trading policy, should be unified step by step. Then a fair and transparent international competition pattern can be built, customs clearance service can be improved and a unified and open market circulation system can be set up.

\section{B. Innovation of Fiscal and Taxation System}

The pushing forward of fiscal and taxation system reform mainly focuses on the existing problems in current fiscal and taxation system, including varied items of administrative charge, various categories of taxes and repetitive taxing. A comprehensive reform experimental area can be set up to initially implement the new fiscal system. A fund for industrial development can be established according to the development plan of Silk Road Economic Region; means including transfer payment and tax reduction and exemption in related segments can be adopted to encourage and cultivate emerging industries as well as to support key construction projects. Policy advantages can be used to conduct tax reduction and exemption on related enterprises engaged in Silk Road trade and then to alleviate their burdens. Domestic enterprises should be encouraged to go global and devote themselves to Silk Road trade. General transfer payment from the exchequer should be strengthened as well as special transfer payments, which cover infrastructure, 
ecological environment, key projects and industrial development. Policy guarantee and support should be ensured to develop competitive industries and build a new starting point of Silk Road.

\section{Innovation of Investment and Financing System}

As to investment system, investment approval procedures should be simplified. In the aspects of project examination, approval, taxation and land, necessary supports should be provided to the base construction concerning advanced equipment manufacturing, high-tech industries and modern high-tech agricultural industries. In accordance with national policies and legislations, private capital should be allowed and encouraged to participant in assets reorganization of state-owned enterprises in forms of joint stock, holding, merger and acquisition

As to financing system, a regional financial system should be built. Taking key cities such as Xi'an as the financial center, construction of regional financial system should be enhanced to provide efficient financial supports for the merchandise trade and flow of productive factors within Silk Road Economic Region. Private capital should be encouraged to establish diversified non-financial investment companies in the form of sole proprietorship or joint stock. "Silk Road Infrastructure Investment Bank" (focusing on construction of transnational high-speed rail, highway and international airport), "Eurasian Bank" (focusing on resource development and industrial development) and "Silk Road Economic Region Development Bank" should be jointly sponsored and set up by adjacent countries. International cooperation platforms, including Shanghai Cooperation Organization Development Bank, Energy Development Bank of West China and coal transaction center, should be fully utilized to satisfy the financing requirements of related trades as well as large-scale construction projects and infrastructure during the Silk Road construction. Local financial institutions should be actively introduced and developed. Local financial resources should be integrated to effectively push forward the merger and reorganization of municipal commercial banks and urban credit cooperatives. Development of private financial institutions should be encouraged, and the establishment of small loan companies, guarantee institutions and pawnbrokers should be supported.

Construction of consultation and cooperation mechanism at cooperate level should be strengthened. Firstly, connection among enterprises involved in the industrial chain should be strengthened. Connection among enterprises involved in the industrial chain should be enhanced while focusing on preferentially developed industrial leading positions and industrial centers; enterprises' external conditions should be fully utilized to form network-based industrial organizations and clusters. Secondly, merger and reorganization should be used to form cross-regional business groups. Through the internalization of industrial linkage as well as merger and reorganization of related enterprises, several cross-regional business groups with the advantage of scale economy can be formed; through transnational and cross-regional alliance among giants, leading enterprises with scale and competitiveness can be formed; the alliance of leading enterprises and the holding of upstream and downstream complementary enterprises can bring out a transnational or cross-regional business group consist of compact layers and loose layers. Thirdly, large-scale enterprises should be led to go global and explore the international market. With the policy and financial supports, large-scale enterprise in west China, such as Xi'an Aircraft Industry (Group) Co., Ltd., should be encouraged and led to explore the foreign markets.

In addition, necessary innovation can be conducted in the aspects of personnel exchanges, international exchanges and cultural cooperation[7]. Adjacent countries along Silk Road should greatly simplify approval procedures of personnel exchanges as well as investment and commercial activities[8]. Thus cultural exchanges, abroad study service, labor dispatching, tourism and business can be promoted, trade costs can be reduced and the economic integration in adjacent countries and regions can be accelerated. Thereinto, simplification degree of visa processing in those countries is especially important. At present, visa processing in majority of the five central Asian countries is extremely strict and the processing period is at least one to two months, which are quite disadvantageous to the economic and cultural exchanges. Even the visa processing in Turkmenistan, a country providing arrival visa to Chinese citizens, is extraordinarily complex. Therefore, simplification of international exchanges is an urgent problem requiring instant solution.

\section{CONCLUSION}

In conclusion, during the development of Silk Road Economic Region, historic opportunity should be seized to effectively push forward System innovation, which can bring continuous impetus for the construction of the economic region and realize new achievements in economy, politics, society and people's livelihood in involved provinces and regions.

\section{ACKNOWLEDGMENT}

Scientific research program funded by Shaanxi provincial education department (program No. 12JK0028), and funded by Xi'an University of Science and Technology and prosperity project of Philosophy and Social Sciences(program No. : 2012SY04、No.2012SZ02)

\section{REFERENCES}

[1] Poelhekke, "Urban Growth and Uninsured $\mathrm{R}$ ural $\mathrm{R}$ isk: Booming Towns in Bust Times ". Journal of Development Economics, Sep.2011,pp. $461 \sim 475$

[2] Chen Liang, Chen Xia, "Wu Hui, Research on the Chinese Potential GDP Growth Rate-Based on the Comparison of Japan, Korea, and Bric countries ," Economic Theory and Economic Management, June.2012, pp. 44-55.

[3] R en Baoping, Han Lu,"Creation of New Bonus Space by Chinese Economic Growth: Mechanism, "Source and Path Selection, Contemporary Economic Research,2014(3),pp. 20-26.

[4] Wang Qingsheng, Yang Qian and etc," Primary Exploration of Issues on the Innovation of Policies", System and Mechanism Concerning In-depth Tourism Resources Development in Tianjin, Pan-Bohai Outlook on Economy, Oct.2010.10,pp 25-29R. Nicole, "Title of paper with only first word capitalized," J. Name Stand. Abbrev., in press. 
[5] Liu Xiaoping, "Analysis on China's Current Fiscal and Taxation System Reform and the Main Problems," China Economic and Trade Herald , Apr.2010,pp 21-22

[6] Ren Baoping, etc, Report of Economic Growth Quality in China (2012), BeiJJing:China Economic Publishing House, 2012,pp. 63 -83 .

[7] Gguo Xiaojie, Liu Wenli, "Research Summary on the Correlation of Technology Innovation, Financial Capital, and Economic Growth"-Concurrently Discuss "Technological Revolutions and Financial Capital" of Carlota Perez, Science and Technology Management Research, Oct.2014,pp. 11-16

[8] Huang Guangcheng, "Silk Road in Southwest China: a Multiple and Three-dimensional Traffic Network," China's Borderland History and Geography Studies, Apr.2002, pp.63-68
[9] Nan Yu and Li Lanjun," Innovation Studies on Cooperation and Development in the Tourist Area of Northwest Silk Road," Journal of the Northwest Adult Education, May.2008, pp.38-40

[10] Wang Wei, "Studies on the System Construction of Tourism Central Cities in China Along Silk Road, "Journal of Ningxia University (Page of Natural Science), Dec.2007, pp.380-383 